\title{
THE ACADEMIC JOURNEY \\ OF ENTREPRENEURSHIP STUDENTS \\ IN HIGHER EDUCATION INSTITUTIONS. THE SYSTEMS THEORY APPROACH
}

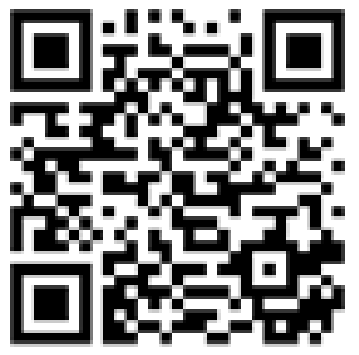

To cite this article:

\author{
Lucky Sibanda, Master of Business Administration \\ (Entrepreneurship) \\ Lecturer (Entrepreneurship and Business Management), \\ Boston City Campus, \\ Stellenbosch, South Africa \\ ckisto@gmail.com \\ https://orcid.org/0000-0002-1421-7337
}

\section{Chux Gervase Iwu*, Prof.}

Head of Department: Entrepreneurship \& Business Management, Cape Peninsula University of Technology,

Cape Town, South Africa

iwuc@cput.ac.za; chuxiwu@gmail.com

https://orcid.org/0000-0002-6290-9864

Corresponding author

Sibanda, L., \& Iwu, C. G. (2021). The academic journey of entrepreneurship students in higher education institutions. The Systems Theory Approach. Education: Modern Discourses, (4), 135-145.

https://doi.org/10.37472/2617-3107-2021-4-13

\begin{abstract}
In its fifth report, South Africa's Department of Higher Education and Training (DHET), published on 31 March 2020, called for institutions to carefully investigate undergraduate business education (curricula) after the business, economics, and management studies (in the Classification of Educational Subject Matter (CESM)) category presented the highest dropouts and lowest throughput rates. To understand the academic journey of entrepreneurship students, this study reviewed the literature through the lens of the General Systems Theory (GST), together with Tuckman's (1999) Tripartite Model of Motivation for Achievement (TMMA). Accordingly, this study viewed the journey of students as a dynamic system with the students having some characteristics and motivations (inputs) when entering higher education, and what the higher education institutions should do (processes) to achieve improved academic performance (output) of students. From the literature reviewed, this study suggests the need to profile students based on their pre-enrolment information and capturing the perceptions of what they think influenced their academic performance in high school. Apart from this, the need to understand the entrepreneurial profile of students has been suggested considering the importance of entrepreneurship in employment creation, especially in South Africa, with an unemployment rate of $32.6 \%$. Thus, it is necessary to produce graduates with the much-needed entrepreneurial capabilities in the South African economy.

Keywords: academic failure; academic performance; academic success; entrepreneurship students; systems theory.
\end{abstract}




\section{INTRODUCTION}

High academic failure rates are commonplace in tertiary institutions in both South Africa and other countries (Schmelzer, Schmelzer, Figler, \& Brozo, 1987; Killen, 1994; Campbell \& Dickson, 1996; Ditcher \& Tetley, 1999; Fraser \& Killen, 2003; Karimi, 2009; Harding, 2012; Aturupane, Glewwe, \& Wisniewski, 2013; DHET, 2020). With access to tertiary education improved, learners pursue admission into well-known programmes in the science disciplines with the hope of securing employment (Isaacs, Visser, Friedrich, \& Brijlal, 2007; Kroon \& Meyer, 2001). This leaves other lesser-known disciplines such as entrepreneurship vulnerable to those students who may not have done well in primary and secondary education. This perhaps explains why the report (DHET, 2020) showed the lowest performance in business studies qualifications. The lowest performance in the DHET report refers to the highest dropout rates and lowest throughput rates; hence calls by the DHET to look at the models underlying undergraduate business education and explore ways of improving student success. This study sought to contribute towards the above by exploring the journey of entrepreneurship students in higher education institutions (HEI).

\section{BACKGROUND}

Since the end of apartheid (after 1994), many researchers have focused on education at tertiary institutions, explicitly focusing on economically marginalised communities. This is like a trend of mass education in the late 1980s in Australia (McKenzie \& Schweitzer, 2001). Due to the imbalances in South Africa during apartheid, blacks were disadvantaged in many ways, one of the areas being education. Blacks in South Africa, during apartheid, mainly were allowed to pursue non-science professions such as teaching and social work (Mustoe, 1967). Post-1994 saw an increased need for enhanced access to higher education for these disadvantaged groups and science disciplines. Considering the dwindling economy of South Africa evidenced by high unemployment of $32.6 \%$ (Stats SA, 2021), research has shown that entrepreneurship will eventually become the panacea for improvement in the economy (Muogbo \& Uchechukwu, 2019), thus necessitating entrepreneurship education (Aduku, Nafiu \& Yakubu, 2016). For example, Shane and Venkataraman (2000) note the enormous role played by entrepreneurship, such as increased economic efficiency and job creation. This has led to a rise in entrepreneurship research in the past few decades (Zhang, Duysters \& Cloodt, 2014). Therefore, there is a critical need to motivate individuals to take up entrepreneurship as a career. Interestingly, increased access has brought challenges to institutions by accommodating various needs for such people, including preparatory courses.

Entrepreneurship education is considered a lifelong learning process consisting of five stages: basics, competency awareness, creative applications, start-up, and growth (Consortium for Entrepreneurship Education [CEE], 2004). Several authors (for example, Enombo, 2015; Nchu, 2015; Mamabolo, 2017; Iwu, Muresherwa, Nchu \& Eresia-Eke, 2020) agree with CEE on the need to expose learners to entrepreneurship from an early stage, such as in primary school. In line with Kroon, De Klerk and Dippenaar's (2003) lifelong entrepreneurship education model, the authors argue that students should be exposed to entrepreneurship education from primary to tertiary.

Since entrepreneurship is critical in providing solutions for national challenges, research focusing on increasing entrepreneurship students' throughput rates should be encouraged. Therefore, this study aims to understand the journey of entrepreneurship students through the lens of the GST. 


\section{METHODOLOGY}

Since descriptive literature review reveals a pattern from the existing literature (Harb \& Abu-Shanab, 2020; Etim \& Iwu, 2019), this study aims to reveal a possible pattern on how students' journey can be depicted in a system, thus deeming this method appropriate. The authors conducted a comprehensive literature search collecting relevant papers focusing on entrepreneurship in higher education. This paper identified previous works relevant to the theme of this study using the following keywords: academic performance, entrepreneurship students, academic success, academic failure, and the systems theory. The sources consulted include secondary data, relevant entrepreneurship textbooks, government publications, conference proceedings, unpublished dissertations, and academic journals in disciplines contributing to the focus area of study (Handzic, 2015; Sharma, Zhang, \& Rai, 2021). The authors then classified the papers into three GST categories namely inputs, processes, and outputs.

\section{THEORETICAL FRAMEWORK}

This research utilised the GST proposed by biologist Ludwig Von Bertalanffy (1968) and TMMA by Tuckman (1999). A system comprises elements that work together to attain the desired goal (Betts, 1992). Tuckman's model (Tuckman, 1999) states that for students to be motivated, lecturers should make efforts to enhance students' attitudes or beliefs in their own capability to impel or propel engagement in the learning process and teach students about relevant strategies. This study views a student's journey in higher education through the lens of a system on which a lecturer motivates students through planned actions to influence their academic performance to succeed.

The GST is a widely used theory in various fields of knowledge (e.g., Oyebade, 2001; Alsabbah \& Ibrahim, 2014; Iwu, Kapondoro, Twum-Darko \& Lose, 2016; Grohs, Kirk, Soledad, \& Knight, 2018). The GST consists of three elements: inputs, processes, and outputs (Hunter, 2012). Similarly, three elements make up the TMMA: attitudes or beliefs about one's capability to attain the outcome, the drive or desire to attain the outcome, and strategy or technique employed to attain the outcome.

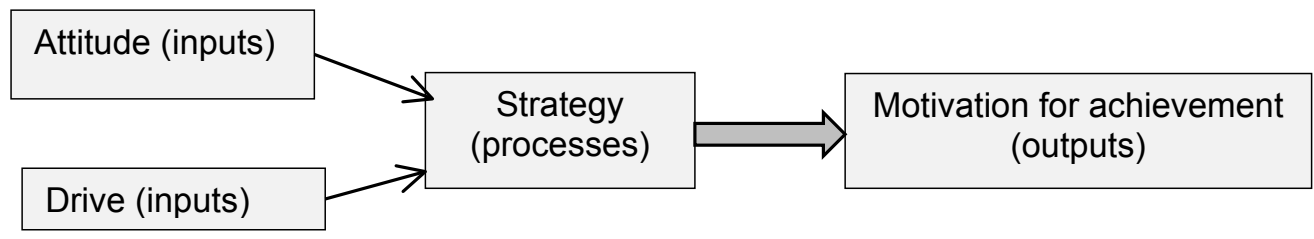

Fig. 1.

Process of improving academic performance (Authors' construction)

Fig. 1 above shows a fusion of the GST and TMMA that demonstrates how a student's attitude and drive (inputs) inform the strategy (process) that impede or facilitate an outcome.

\section{LITERATURE REVIEW}

The presentation of the literature follows the integration of the GST, together with the TMMA. Thus, the literature consists of three sections according to the GST (i) inputs, (ii) processes, and (iii) outputs. The TMMA process relates to the three components of the GST. It states that for the outcome (output) to be achieved in the form of motivated students, the 
learning process should take place with the inputs being the efforts by the teachers, attitudes or beliefs and drive of students' capabilities. Keeping this in mind, the following sections discuss the different components of a system.

\section{Inputs (attitude and the drive to pursue entrepreneurship qualification)}

Herrington, Kew and Mwanga (2017) posit that South Africa's low score for the quality of entrepreneurship education and training in primary and secondary schools is a result of the deficiencies in the primary education system, which concur with an earlier finding by The 2016 National Experts' Survey (NES). Herrington et al. (2017) cement the NES's credibility in capturing expert judgements evaluating specific national conditions influential in creating unique business and entrepreneurial contexts. Furthermore, not only are teachers not trained in entrepreneurship despite entrepreneurship being one of the learning outcomes from Grade $\mathrm{R}$ to 12 , but they also lack the resources for high school entrepreneurship teaching (Nchu, 2015), thus suggesting that entrepreneurship is not taught adequately in high school, which influences students to seek employment instead. Therefore, there is a need to establish the under-preparedness of students towards higher education per cohort before proposing any interventions.

Isaacs et al. (2007) noted that entrepreneurship in high school is not prioritised as it should be. Thus, a suggestion for a complete overhaul has been made for the South African education system to teach competencies that are relevant to the modern economy at every level of schooling. Therefore, there is a need to profile the students based on their preenrolment information, thus capturing the perceptions of what they think influenced their academic performance in high school. Viviers, Solomon and Venter (2013) reported a higher level of awareness of theoretically based entrepreneurship offerings than more practical offerings among students. Grecu and Denes (2017) pointed out that entrepreneurial education and training advance individuals through developing self-esteem, the ability to recognise commercial opportunities, and the knowledge and skills to act on them.

\section{Processes (strategy - entrepreneurship education)}

Lecturers are in a better position to educate students through curriculum development, conducive learning environment, offering relevant academic support, and teaching and learning methods. Ozaralli and Rivenburgh (2016) state that efforts to foster entrepreneurship through education and training were initiated in the 1940s when the Harvard Business School introduced the first entrepreneurship course. One of the ways of nurturing entrepreneurship is through entrepreneurial education, according to Nchu (2015) and other studies (Radipere, 2012; Timmons \& Spinelli, 2004; Kusmintarti, Thoyib, Maskie, \& Ashar, 2016) which found that the number of start-ups might increase which may lead to job creation and economic growth. South African tertiary institutions should embed entrepreneurial education in their curriculum (Radipere, 2012; Tengeh et al., 2015). This would ensure that graduates are exposed to the entrepreneurial field and possibly start their own business in future (World Economic Forum, 2009; Kilasi, 2013). Entrepreneurship education plays a significant role in awakening entrepreneurial intentions. It helps students turn vague intentions of starting a business into realities (Zain, Akram \& Ghani, 2010; Claire \& Perryman, 2016; Ndala, 2019).

The Global University Entrepreneurial Spirit Students Survey (GUESSS) has measured the entrepreneurial intentions of university students since 2003 (Sieger, Fueglistaller, Zellweger \& Braun, 2018). The 3000 universities which participated in 2018 had about 208000 student participants from 54 countries across the globe. Generally, students from all countries indicated positive benefits of attending entrepreneurial courses such as developing business networks and identifying business ideas (Sieger et al., 2018). 
It is logical to attribute the low level of entrepreneurship education and training to student attrition in all study levels, i.e., primary, secondary, vocational, and tertiary. Anyone who drops out of education would probably look for employment; hence, if such individuals have achieved entrepreneurial competencies before dropping out, they might somehow consider starting a business after getting employment. Lecturers should develop interventions embedded in their teaching and learning to improve the students' academic performance and prepare them to become graduates. In fact, Iwu et al. (2021) found that a substantial percentage of students linked their lack of interest in entrepreneurship to the incompetency of their lecturers. Some educational institutions have thus far started to respond to the government call to encourage individuals to become entrepreneurs. Thus, they have started implementing learning courses associated with entrepreneurship education, including business plans, business concepts, and networking, to stimulate entrepreneurship intention and attributes towards self-employment (Musetsho \& Lethoko, 2017). Mamabolo (2017) suggests that educators adopt experimental and action teaching methods that help entrepreneurs learn skills from simulating experiences.

At the tertiary level, Botha and Bignotti (2016) conducted a study that included all South African government-funded universities and suggested the need to include internships as part of the entrepreneurship programmes due to the positive influence on entrepreneurial selfefficacy and entrepreneurial intent. Similarly, Mamabolo (2017) suggests training institutions should incorporate entrepreneurship development in the curriculum as early as primary school and throughout secondary and tertiary institutions. Furthermore, Herrington et al. (2017) suggest a need for increased investment in training programmes outside of traditional higher education institutions to replicate privately sponsored models such as the Tertiary School in Business Administration (TSiBA), the Fast-Track programme at Sasol and South African Breweries' KickStart programme. Despite the need to include internships as part of entrepreneurship programmes, tertiary institutions and participating businesses face some challenges. Botha and Bignotti (2016) highlight the lack of mentoring capacity, curriculum redesign, and administrative issues as some of the challenges. Mamabolo (2017) stresses access to mentoring and coaching as challenges facing entrepreneurs. To integrate internship programmes, tertiary institutions must begin by identifying businesses with mentoring and coaching capacity to participate in internship programmes.

\section{Outputs (motivation for achievement)}

Typically, the prospects of gaining knowledge should drive students to complete an entrepreneurship qualification (Nicolaides, 2011). Part of the outcomes for entrepreneurship qualifications is to equip students with the knowledge to establish businesses, possibly increasing entrepreneurial activity once students graduate. Various studies show that while graduates consider taking up employment soon after graduation, they also consider establishing businesses later. A study by Kroon and Meyer (2001) claim that South Africans seek financially secure jobs rather than establish their businesses. Graduates tend to become entrepreneurial five years after graduation (Viviers et al., 2013). Similarly, the GUESSS, in its 2018 survey, revealed that most students prefer to find employment before venturing into entrepreneurship (Sieger et al., 2018). Therefore, this paper argues that employment is a primary driver of completing qualifications.

The DHET highlights the need for universities to ensure quality graduates from the system providing the skills required for South Africa's economic development (DHET, 2020). One of the most pressing issues facing the nation is to create enough jobs for its people. Thus, entrepreneurship students should develop entrepreneurial capabilities, compete in the Fourth Industrial Revolution (4IR), and create employment soon after graduating. With the awareness of the desired graduate attributes, students should source their motivation from the 
well-documented information regarding high failure rates and then work hard to complete their qualifications. Taking longer to complete a qualification has negative consequences, and students should avoid such implications by working hard.

Entrepreneurship education develops student' skills to be enterprising. Fatoki and Oni (2014) posit that entrepreneurship education has two effects on students. Firstly, it encourages students to take entrepreneurship as a career and secondly, it provides students with the essential skills to be entrepreneurial. In their study, Mbuya and Schachtebeck (2016) found that entrepreneurship students strongly desire to start a business after completing their studies compared to students studying non-entrepreneurship qualifications. Similarly, Letsoalo and Rankhumise (2020) found a positive relationship between studying entrepreneurship courses and starting a business among non-first year students. Furthermore, Letsoalo and Rankhumise (2020) found that entrepreneurial intention increases as students further their studies. Enterprising graduates can, in turn, boost economic activities (Aduku, Nafiu \& Yakubu, 2016). Therefore, entrepreneurship education is critical, and higher institutions should nature it.

\section{DISCUSSION}

The academic journey of entrepreneurship students is complex, just like other students studying for other qualifications. While Tinto's student attrition model is commonly used to understand the student journey in HE (Lee et al., 2021), this study proposes a different approach that infuses the GST with the TMMA to achieve a related outcome. With the proposed approach, this study divides the students' journey into three stages: inputs, processes, and outputs. Institutions attracting students with varied backgrounds (inputs) need to customise student support interventions (processes) to address the unique variables among students, thus achieving the desired attributes among graduates.

\section{Output: The necessity of entrepreneurship education}

The current high unemployment rate in South Africa signifies the employment creation efforts to come from both the public and private sectors. It is also evident on the rise of graduate unemployment (Oluwajodu et al., 2015). This calls for tertiary institutions to re-consider the graduate attributes imparted upon graduation among other aspects critical for graduates. In South Africa, the importance of entrepreneurship is acknowledged through government policies which have been designed to promote entrepreneurship across all levels of education. Since entrepreneurial activity has been found to be associated with employment levels in developing countries (Aduku et al., 2016; Omotayo, Adeyemi \& Adebanjo-Adenugba, 2020; Musara et al., 2020), there is a need for tertiary institutions in South Africa and other developing countries to pay more attention on students' graduate attributes. Entrepreneurship students should be developed and empowered to be entrepreneurial before and soon after graduation. Thus, government policies in various countries should encourage universities to include at least a module in entrepreneurship at the tertiary level. In this way, students graduate with basic knowledge of establishing their businesses.

\section{Process: The importance of competent lecturers and a sound curriculum}

The role of lecturers is critical towards shaping the graduate attributes in HE. Through the curriculum, institutions can instil entrepreneurial attributes to achieve the desired graduate attributes. Achieving the desired graduate attributes calls for competent lecturers taking appropriate actions using the curriculum. One way to achieve this is for lecturers to engage in academic research to determine and implement appropriate evidence-based interventions towards the expected graduate attributes. Despite the possibility of having qualified and experienced lecturers to implement interventions that develops the desired graduate attributes, 
institutional policies should be conducive to allow such. Thus, graduate attributes development should begin with the whole institution embracing such an initiative then implemented at a department level. Otherwise, lecturers' efforts to promote the desired graduate attributes may be frustrated.

\section{Input: The significance of teaching entrepreneurship from an early age}

It is critical for entrepreneurship development to be prioritised at all educational levels. Instead of focusing on it at the tertiary level, policies should instead integrate entrepreneurial development at an early stage, such as on the primary and secondary levels of education (Iwu et al., 2020). Research points out the under-preparedness of students is a critical factor towards the academic performance of students at the tertiary level (Ramaila \& Seloane, 2020). Thus, teaching entrepreneurship at an early stage would positively contribute to the graduate attributes and student academic success at the tertiary level.

\section{STUDY LIMITATIONS, SUGGESTIONS FOR FURTHER RESEARCH AND RECOMMENDATIONS}

This study adopted a descriptive literature review method mostly criticised for being less rigorous. Thus, literature is limited to accessible text deemed relevant to the current study by the researchers. Therefore, a more robust and comprehensive literature review method can be applied to understand entrepreneurship students' academic journey, such as a systematic literature review. Following a GST, a causal relationship exists among the identified stages of the students' academic journey: inputs, processes and outputs. This study suggests but does not statistically test these relationships among the stages. There is a need to investigate more elements in the suggested system further to understand the complex journey of students at tertiary institutions. This study suggests a basic system that can potentially guide lecturers and education administrators in higher education to improve students' academic performance. Thus, potential future research would be to implement this guideline towards developing evidencebased academic interventions and periodically reviewing them. Lecturers are encouraged to develop academic interventions aligned with the needs of a specific cohort rather than one size fits all approach.

\section{CONCLUSION}

This study established the critical role academic administrators and lecturers should play in students' academic journey in Higher Education Institutions (HEI). There is a need to view the students' academic journey as a dynamic process that can be monitored and controlled using two theories. This paper discussed the GST by Von Bertalanffy (1968) and the TMMA by Tuckman (1999) and the link between the two. The paper observed three linking aspects from both theories and these are students' attitudes about their capabilities to succeed, their drive to succeed (input), and the strategies employed (processes) to attain the desired outcome (output). Furthermore, there is a need to conduct research that seeks to understand the academic interventions that are effective in entrepreneurship education. This study concludes that institutions can achieve the desired graduate attributes (output) through evidence-based student support interventions (processes) that factor in unique student backgrounds (inputs).

\section{REFERENCES}

Aduku, D. J., Nafiu, A. T. \& Yakubu, S. (2016). Imperative of Practical Entrepreneurship Education for Nigeria in the World of Economic Reality. IOSR Journal of Business Management, 18(6), $60-68$. 
Alsabbah, M. Y. \& Ibrahim, H. (2014). HRM practices and employee competence: A general system perspective. International Journal of Business, Economics and Law, 4(1), 11-17.

Aturupane, H., Glewwe, P. \& Wisniewski, S. (2013). The impact of school quality, socioeconomic factors, and child health on students' academic performance: evidence from Sri Lankan primary schools. Education Economics, 21(1), 2-37.

Betts, F. (1992). How systems thinking applies to education. Educational leadership, 50(3), 38-41.

Botha, M. \& Bignotti, A. (2016). Internships are enhancing entrepreneurial intent and self-efficacy: Investigating tertiary-level entrepreneurship education programmes. The Southern African Journal of Entrepreneurship and Small Business Management, 8(1), 1-15.

Campbell, A. R. \& Dickson, C. J. (1996). Predicting student success: A 10-year review using integrative review and meta-analysis. Journal of Professional Nursing, 12(1), 47-59.

Claire, L. \& Perryman, A. A. (2016). Where's Waldo? The search for entrepreneurial role models. Journal of Entrepreneurship Education, 19(1), 91-102.

Consortium for Entrepreneurship Education, (2004). Lifelong Learning Model. Retrieved 2020 from https://www.education.ne.gov/entreped/lifelong-learning-model/

Department of Higher Education and Training (DHET). (2020). 2000 to 2020 First time entering undergraduate cohort studies for public higher education institutions. DHET, Pretoria.

Ditcher, A. \& Tetley, J. (1999). Factors influencing university students' academic success: what do students and academics think? Paper presented at HERDSA Annual International Conference, Melbourne, 12-15 July 1999.

Enombo, P. G. J. (2015). A needs analysis for entrepreneurship education in selected high schools in Libreville, Gabon. Unpublished Masters Dissertation, Cape Peninsula University of Technology, Cape Town.

Etim, E., \& Iwu, C. G. (2019). A descriptive literature review of the continued marginalisation of female entrepreneurs in sub-Saharan Africa. International Journal of Gender Studies in Developing Societies, 3(1), 1-19.

Fatoki, O. \& Oni, O. (2014). Students' perception of the effectiveness of entrepreneurship education at a South African University. Mediterranean Journal of Social Sciences, 5(20), 585-591.

Fraser, W. J. \& Killen, R. (2003). Factors influencing academic success or failure of first year and senior university students: do education students and lecturers perceive things differently? South African Journal of Education, 23(4), 254-260.

Grecu, V. \& Denes, C. (2017). Benefits of entrepreneurship education and training for engineering students. MATEC Web of Conferences 121(12007), 1-7.

Grohs, J. R., Kirk, G. R., Soledad, M. M. \& Knight, D. B. (2018). Assessing systems thinking: A tool to measure complex reasoning through ill-structured problems. Thinking Skills and Creativity, 28, 110-130.

Handzic, M. (2015). A descriptive analysis of knowledge management research: Period from 1997 to 2012. In: Bolisani, E. and Handzic, M. (eds) Advances in knowledge management. Knowledge management and organizational learning, vol 1. Springer, Cham, 45-64.

Harb, Y. \& Abu-Shanab, E. (2020). A descriptive framework for the field of knowledge management. Knowledge and Information Systems, 62(12), 4481-4508.

Harding, M. (2012). Efficacy of supplemental instruction to enhance student success. Teaching and learning in Nursing, 7, 27-31.

Herrington, M., Kew, P. \& Mwanga, A. (2017). GEM South Africa report 2016/2017: Can small Businesses survive in South Africa? University of Cape Town, Cape Town.

Hunter, C. (2012). Managing People in South Africa: Human Resource Management as a Competitive Advantage. $2^{\text {nd }}$ ed. Durban: Sherwood Books. 
Isaacs, E., Visser, K., Friedrich C. \& Brijlal, P. (2007). Entrepreneurship education and training at the further education and training (FET) level in South Africa. South African Journal of Education, 27(4), 613-629.

Iwu, C. G., Opute, P. A., Nchu, R., Eresia-Eke, C., Tengeh, R. K., Jaiyeoba, O., \& Aliyu, O. A. (2021). Entrepreneurship education, curriculum and lecturer-competency as antecedents of student entrepreneurial intention. The International Journal of Management Education, 19(1), 1-13.

Iwu, C. G., Kapondoro, L., Twum-Darko, M. \& Lose, T. (2016). Strategic human resource metrics: A perspective of the general systems theory. Acta Universitatis Danubius: Oeconomica,

Iwu, C. G., Muresherwa, G., Nchu, R. \& Eresia-Eke, C. E. (2020). University Students' Perception of Entrepreneurship as a Career Option. Academia, (20-21), 177-201.

Karimi, F. K. (2009). Factors contributing to academic performance of students in a private university in Kenya. Unpublished doctoral dissertation, University of South Africa, Pretoria.

Kilasi, P. K. (2013). The role of higher education in promoting entrepreneurship education. The case of public universities in Tanzania. Dissertation Submitted for Award of PhD Degree at University of Pretoria: South Africa

Killen, R. (1994). Differences between students' and lecturers' perceptions of factors influencing students' academic success at university. Higher Education Research and Development, 13(2), 199-212.

Kroon, J. \& Meyer, S. (2001). The role of entrepreneurship education in career expectations of students. South African Journal of Higher Education, 15(1), 47-53.

Kroon, J., De Klerk, S. \& Dippenaar, A. (2003). Developing the next generation of potential entrepreneurs: co-operation between schools and business. South African Journal of Education, 23(4), 319-322.

Kusmintarti, A., Thoyib, A., Maskie, G. \& Ashar, K. (2016). Entrepreneurial characteristics as a mediation of entrepreneurial education influence on entrepreneurial intention. Journal of Entrepreneurship Education, 19(1), 24-37.

Lee, W. C., Hall, J. L., Godwin, A., Knight, D. B. \& Verdín, D. (2021). Operationalizing and monitoring student support in undergraduate engineering education. Journal of Engineering Education, 1-29. Retrieved 2021 from https://onlinelibrary.wiley.com/doi/pdf/10.1002/ jee.20431

Letsoalo, M. E. \& Rankhumise, E. M. (2020). Students' entrepreneurial intentions at two South African universities. Journal of Entrepreneurship Education, 23(1), 1-14.

Mamabolo, M. A. (2017). Human capital investments and skills outcomes specific to the different entrepreneurship phases. Unpublished PhD Thesis, University of Pretoria.

Mbuya, J. M. \& Schachtebeck, C. (2016). Future entrepreneurs: Does the field of study matter? A comparison of students in a South African urban environment. Problems and Perspectives in Management, 14(2), 228-235.

McKenzie, K. \& Schweitzer, R. (2001). Who succeeds at university? Factors predicting academic performance in first year Australian university students. Higher Education Research \& Development, 20(1), 21-33.

Muogbo, U. S. \& Uchechukwu, E. S. (2019). Entrepreneurship development as a panacea for depressed economy. International Journal of Business and Applied Social Science, 5(11), 29-37.

Musara, M., Mabila, T., Gwaindepi, C., \& Dhoro, N. (2020). Entrepreneurial activity for economic growth and unemployment reduction in South Africa. International Journal of Entrepreneurship, 24(2), 1-8.

Musetsho, T. R. \& Lethoko, M. X. (2017). An evaluative study on the effect of entrepreneurial education curriculum on students at the University of Venda, South Africa. The Independent Journal of Teaching and Learning, 12(1), 74-89. 
Mustoe, N. (1968). Apartheid: its effects on education, science, culture and information. Retrieved 2021 from https://unesdoc.unesco.org/ark:/48223/pf0000002428

Nchu, R. M. (2015). The effectiveness of entrepreneurship education in selected high schools in the Cape Town metropolitan. Unpublished Masters Dissertation, Cape Peninsula University of Technology, Cape Town.

Ndala, N. N. (2019). Investigating the effectiveness of entrepreneurship education in developing entrepreneurial intentions among students in HEIs located in Blantyre District of Malawi. African Journal of Business Management, 13(3), 105-115.

Nicolaides, A. (2011). Entrepreneurship - the role of higher education in South Africa. Educational Research, 2(4), 1043-1050.

Oluwajodu, F., Greyling, L., Blaauw, D. \& Kleynhans, E. P. (2015). Graduate unemployment in South Africa: Perspectives from the banking sector. SA Journal of Human Resource Management, 13(1), 1-9.

Omotayo, O. T., Adeyemi, V. S. \& Adebanjo-Adenugba, O. A. (2020). Entrepreneurship As a Tool for Reducing Unemployment Among Nigerian Youth. Journal Of Contemporary Issues in Educational Planning and Administration, 5(2), 85-94.

Oyebade, S. A. (2001). Applying the general systems theory to students' conflict management in Nigeria's tertiary institutions. Lagos Journal of Educational Administration and Planning, 1 (1), 36-49.

Ozaralli, N. \& Rivenburgh, N. K. (2016). Entrepreneurial intention: antecedents to entrepreneurial behaviour in the USA and Turkey. Journal of Global Entrepreneurship Research, 6(3), 1-32. https://doi.org/10.1186/s40497-016-0047-x

Radipere, S. (2012). South African university entrepreneurship education. African Journal of Business Management, 6(44), 11015-11022.

Ramaila, S. \& Seloane, P. (2020). South African at-risk undergraduate engineering students' perceptions of the remedial intervention designed to enhance their academic performance in mathematics as a key knowledge domain. Education and New Developments, 96-99.

Schmelzer, R. V., Schmelzer, C. D., Figler, R. A. \& Brozo, W. G. (1987). Using the critical incident technique to determine reasons for success and failure of university students. Journal of College Student Personnel, 28, 261-266.

Shane, S. \& Venkataraman, S. (2000). The promise of entrepreneurship as a field of research. Academy of management review, 25(1), 217-226.

Sharma, A., Zhang, Z., \& Rai, R. (2021). The interpretive model of manufacturing: a theoretical framework and research agenda for machine learning in manufacturing. International Journal of Production Research, 59(16), 4960-4994.

Sieger, P., Fueglistaller, U., Zellweger, T. \& Braun, I. (2018). Global student entrepreneurship 2018: Insights from 54 countries. Global GUESSS Report, 1-32.

Stats SA, (2021). Quarterly Labour Force Survey (QLFS): Quarter 1, Media Release. Pretoria; Stats SA. Retrieved 2021 from http://www.statssa.gov.za/publications/P0211/Media\%20 release\%20QLFS\%20Q1\%202021.pdf

Tengeh, R. K., Iwu, C. G. \& Nchu, R. M. (2015). The embeddedness of entrepreneurship education in the curricula of non-business university programmes: Preliminary evidence from South African Universities of Technology. Socioeconomica, 4(7), 111-126.

Timmons, J. A. \& Spinelli, S. (2004). New Venture Creation: Entrepreneurship for the 21st Century. Boston: McGraw-Hill.

Tuckman, B. W. (1999). A tripartite model of motivation for achievement: attitude/drive/strategy. Paper presented at the symposium, Motivational Factors Affecting Student Achievement Current Perspectives, annual meeting of the American Psychological Association, Boston. 
Viviers, S., Solomon, G. \& Venter, C. (2013). Entrepreneurial intentions and behaviours of South African University students. The Southern African Journal of Entrepreneurship and Small Business Management, 6(1), 1-20.

Von Bertalanffy, L. (1968). General System Theory: Foundations, Development, Applications. New York: George Braziller.

World Economic Forum. (2009). Educating the Next Wave of Entrepreneurs: Unlocking Entrepreneurial Capabilities to Meet the Global Challenges of the 21 ${ }^{\text {st }}$ Century: A Report of the Global Education Initiative. Switzerland: World Economic Forum.

Zain, Z. M., Akram A. M. \& Ghani, E. K. (2010). Entrepreneurship intention among Malaysian business students. Canadian Social Science, 6(3), 34-44.

Zhang, Y., Duysters, G. \& Cloodt, M. (2014). The role of entrepreneurship education as a predictor of university students' entrepreneurial intention. International entrepreneurship and management journal, 10(3), 623-641. 